University of Nebraska - Lincoln

DigitalCommons@University of Nebraska - Lincoln

USDA National Wildlife Research Center - Staff Publications
U.S. Department of Agriculture: Animal and Plant Health Inspection Service

2013

\title{
Determination of an Immunocontraceptive Peptide in a Wildlife Vaccine Formulation
}

\author{
David A. Goldade \\ Jeffrey M. Kemp \\ USDA/APHIS/WS/National Wildlife Research Center \\ Jeanette R. O'Hare \\ USDA/APHIS/WS/National Wildlife Research Center \\ Lowell A. Miller \\ USDA/APHIS/WS/National Wildlife Research Center
}

USDA/APHIS/WS/National Wildlife Research Center, David.A.Goldade@aphis.usda.gov

Follow this and additional works at: https://digitalcommons.unl.edu/icwdm_usdanwrc

Part of the Life Sciences Commons

Goldade, David A.; Kemp, Jeffrey M.; O'Hare, Jeanette R.; and Miller, Lowell A., "Determination of an Immunocontraceptive Peptide in a Wildlife Vaccine Formulation" (2013). USDA National Wildlife Research Center - Staff Publications. 1483.

https://digitalcommons.unl.edu/icwdm_usdanwrc/1483

This Article is brought to you for free and open access by the U.S. Department of Agriculture: Animal and Plant Health Inspection Service at DigitalCommons@University of Nebraska - Lincoln. It has been accepted for inclusion in USDA National Wildlife Research Center - Staff Publications by an authorized administrator of DigitalCommons@University of Nebraska - Lincoln. 


\title{
Chapter 6
}

\section{Determination of an Immunocontraceptive Peptide in a Wildlife Vaccine Formulation}

\author{
David A. Goldade, ${ }^{*}$ Jeffrey M. Kemp, ${ }^{1}$ Jeanette R. O'Hare, and \\ Lowell A. Miller
}

\author{
USDA/APHIS/WS/National Wildlife Research Center, 4101 LaPorte Avenue, \\ Fort Collins, Colorado 80521 \\ 1Present address: Colorado Serum Company, 4950 York Street, \\ Denver, Colorado 80216 \\ ^E-mail: David.A.Goldade@aphis.usda.gov
}

\begin{abstract}
Wildlife populations continue to grow despite the use of traditional management techniques. GonaCon ${ }^{\mathrm{TM}}$ Immunocontraceptive Vaccine is a vaccine used to reduce reproduction in mammalian species, including white-tailed deer (Odocoileus virginianus). The vaccine consists of synthetic gonadotropin releasing hormone (GnRH) conjugated to a mollusk hemocyanin (Concholepas concholepas) prepared as an emulsion with mineral oil to promote a prolonged immune response. Development of an analytical method for determination of the active ingredient in the vaccine formulation was complicated by the emulsion and conjugation of $\mathrm{GnRH}$ to the carrier protein. Breaking the emulsion was achieved chemically by addition of diethyl ether. The aqueous portion containing the GnRH conjugate was cleaved enzymatically with a protease (clostripain) at the arginine-proline site of its peptide sequence. Hydrolysis produced a diagnostic eight amino acid peptide fragment which was unique to $\mathrm{GnRH}$ and easily quantified by LC/MS/MS. Typical recoveries of fortified samples at the target concentration exceeded $90 \%$.
\end{abstract}




\section{Introduction}

Wildlife populations, in particular wild deer populations have been steadily increasing since the early 1900's when population estimations placed the number of wild deer in the US at approximately 500,000 (1). Restocking and conservation efforts were undertaken to replenish the populations. These efforts have been extremely successful to the point that a serious overpopulation problem now exists, particularly in urban and suburban areas (2). Current population estimates are in the neighborhood of 20 million individuals. Population densities can reach as much as 40 to 100 individuals per square mile in some urban and suburban areas (3). These high population densities can lead to severe wildlife management issues including increased deer-vehicle collisions (4), damage to ornamental plants or crops (5), degradation of habitat quality for other wildlife due to overgrazing ( 6 , $7)$, and possible disease transmission to other wild or domestic animals as well as human populations $(8,9)$.

Management techniques typically employed to minimize deer-human conflicts in rural settings include culling, the use of scare devices, or exclusion fences. Firing high powered rifles in urban areas has very little support from members of the public who live in the areas where control is needed $(10)$. Scare devices are either wholly ineffective or are only effective for a short time before the animals become habituated to them $(11,12)$. Exclusion fences are not practical in many settings, can be cost prohibitive, and must be extremely tall in order to keep highly agile deer from jumping over them (13). Ecosystem controls such as the introduction of predators is not feasible in urban settings (14). A long-term management solution must include new tools in an integrated approach. A technique such as immunocontraception used to limit reproduction of local populations is such a tool.

GonaCon ${ }^{\mathrm{TM}}$ Immunocontraceptive Vaccine (hereafter GonaCon ${ }^{\mathrm{TM}}$ ) is an immunocontraceptive vaccine registered with the Environmental Protection Agency (EPA) under the Federal Insecticide, Fungicide, and Rodenticide Act (FIFRA) for use with female white-tailed deer 1 year of age or older (15). In addition to registration with EPA, use of this product requires registration within each state and approval by the State natural resource agency responsible for managing wildlife. Currently, it is only registered for use in New Jersey and Maryland.

GonaCon ${ }^{\mathrm{TM}}$ consists of a synthetic gonadotropin releasing hormone peptide (GnRH) conjugated to a mollusk hemocyanin (blue protein or BP). The conjugated protein is mixed with mineral oil and a surfactant to produce an emulsion $(16,17)$. The final vaccine emulsion is delivered to the target animals via a 1 $\mathrm{mL}$ intra-muscular injection $(17,18)$. The conjugated protein stimulates the production of antibodies that bind to endogenous GnRH. By binding to GnRH, the antibodies reduce GnRH's ability to stimulate the production of sex hormones such as estrogen, progesterone, and testosterone. As a result, all sexual activity is decreased and the animals remain in a nonreproductive state as long as a sufficient level of antibody activity is present. 
In order to support the continued registration of GonaCon ${ }^{\mathrm{TM}}$, an Enforcement Analytical Method is required by the EPA. The method needed to be accurate and reliable. It also needed to be sensitive enough to detect small differences in the active ingredient content of the final vaccine.

\section{Methods}

\section{Reagents}

Formic acid (LC-MS Grade), DL-dithiothreitol, 2,2,2-trifluoroethanol, and calcium chloride dihydrate were all obtained from Sigma-Aldrich (St. Louis, $\mathrm{MO}$ ). Acetonitrile (Optima Grade), diethyl ether (anhydrous), sodium phosphate monobasic, and potassium hydroxide were obtained from Fisher Scientific (Pittsburgh, PA). Clostripain (87 units/mg dry weight; Endoproteinase-Arg-C) was purchased from Worthington Biochemical (Lakewood, NJ). Gonadotropin releasing hormone (GnRH; [pE]HW SYG LRP GGC-CONH2; 95.42\% pure) was synthesized by GL Biochem (Shanghai, China). Peptide-1 ([Pyr]HWSYGLR-Acid; $97.39 \%$ pure) was synthesized by Pi Proteomics (Huntsville, AL).

The mobile phase consisted of a mixture of $0.1 \%$ formic acid in deionized water and acetonitrile. Deionized water was purified using an E-Pure water purification system (Barnstead, Dubuque, IA). The sample extraction solution was prepared by combining approximately $0.36 \mathrm{~g}$ of sodium phosphate monobasic and $40 \mathrm{mg}$ of DL-dithiothreitol in $60 \mathrm{~mL}$ deionized water. The $\mathrm{pH}$ was adjusted to approximately 7.6 with a solution of $1 \mathrm{M}$ potassium hydroxide. To this solution $5 \mathrm{~mL}$ of 2,2,2-trifluoroethanol was added before diluting to a final volume of $100-\mathrm{mL}$ with deionized water. The enzyme activation solution was prepared by combining approximately $15 \mathrm{mg}$ of calcium chloride dihydrate and $40 \mathrm{mg}$ of DL-dithiothreitol. The solution was diluted to $100 \mathrm{~mL}$ with deionized water before use.

A concentrated stock solution of GnRH and Peptide-l was prepared by weighing $1.000 \mathrm{mg}$ of each and dissolving them in $5.00 \mathrm{~mL}$ of deionized water. Working standards, ranging in concentration from $10 \mathrm{ng} / \mathrm{mL}$ to $2 \mu \mathrm{g} / \mathrm{mL}$, were prepared by dilution of stock solutions with a solution of $9: 10.1 \%$ formic acid in deionized water:0.1\% formic acid in acetonitrile. All standard solutions were stored at $5^{\circ} \mathrm{C}$ prior to use. A representative chromatogram is shown in Figure 1.

\section{Sample Analysis}

\section{Breaking the Emulsion}

GonaCon ${ }^{\mathrm{TM}}$ vaccine aliquots $(0.5 \mathrm{~g})$ were placed in $15-\mathrm{mL}$ glass centrifuge tubes. One milliliter of extraction solution was added to each sample. The sample was vortexed to suspend the vaccine material followed by centrifugation at approximately $5,000 \mathrm{~g}$ for 2 minutes. Diethyl ether was used to break the emulsion and separate the mixture into an organic and aqueous layer. This was 
accomplished by adding three successive $5 \mathrm{~mL}$ aliquots of ether followed by a vortexing and centrifugation step to separate the organic and aqueous layers. The upper, organic layer was discarded and the aqueous layer was transferred to a $5-\mathrm{mL}$ volumetric flask and diluted to produce a solution containing $5 \%$ trifluoroethanol in phosphate buffer.

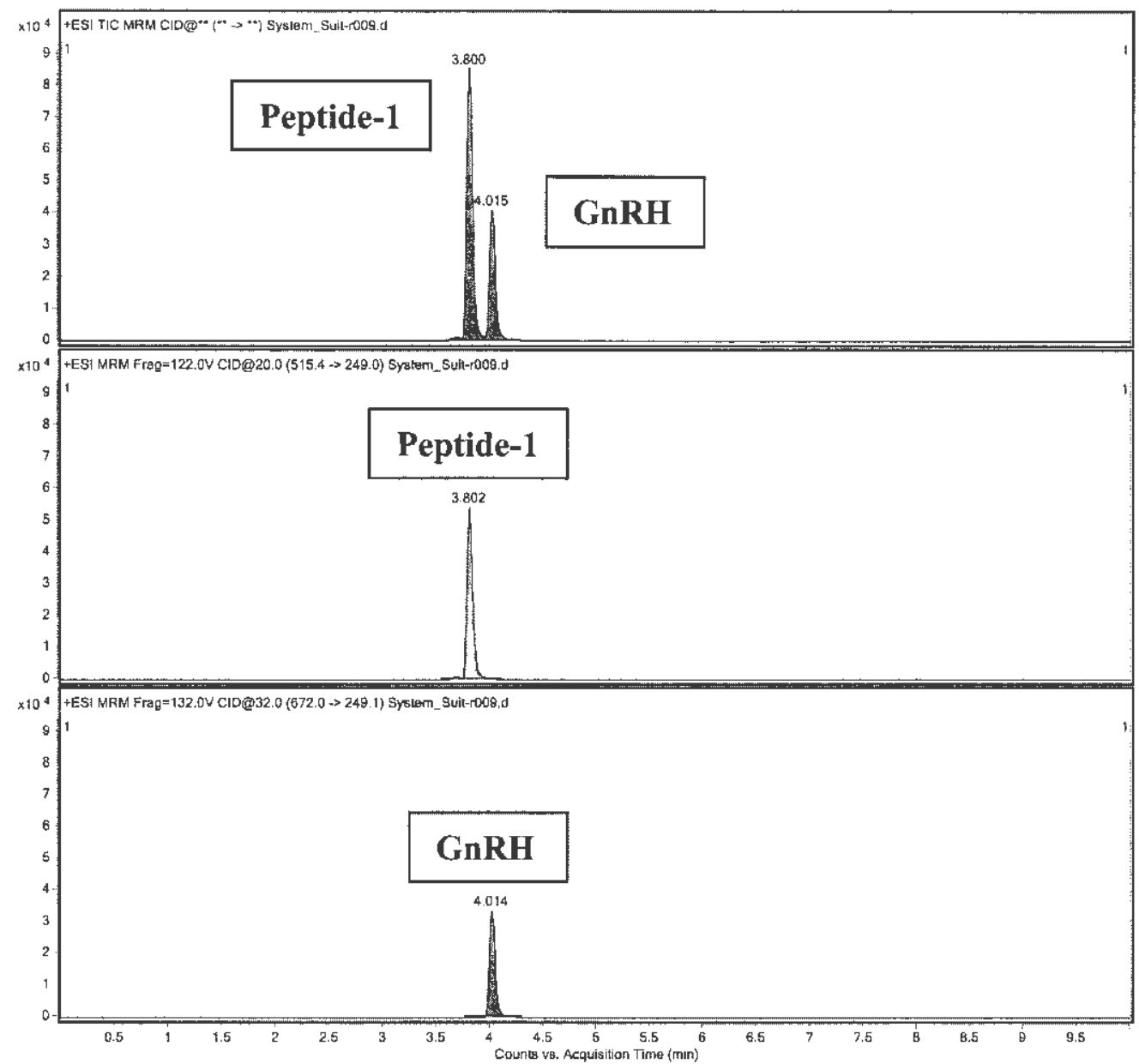

Figure 1. Chromatogram of a $500 \mathrm{ng} / \mathrm{mL}$ standard solution.

\section{Enzymatic Cleavage}

A solution of activated clostripain was prepared by weighing approximately $0.25 \mathrm{mg}$ of clostripain into a $1.5-\mathrm{mL}$ microcentrifuge tube and adding $1 \mathrm{~mL}$ of enzyme activation solution. A $50 \mu \mathrm{L}$ aliquot of sample extract was removed and reacted with $50 \mu \mathrm{L}$ of the clostripain solution in $1 \mathrm{~mL}$ of extraction solution to produce the peptide fragment. The enzyme reaction was conducted in a water bath held at approximately $25^{\circ} \mathrm{C}$ for two hours. Following completion of the reaction, 
$1 \mathrm{~mL}$ of a solution of $8: 20.1 \%$ formic acid in deionized water:0.1\% formic acid in acetonitrile was added and the sample was centrifuged to remove any heavy protein fragments. This clarified solution was injected into the LC/MS/MS and the concentration of the diagnostic peptide fragment was quantified. Each sample was analyzed for both total GnRH content and free (or unconjugated) GnRH content by preparing a second sample which contained all of the components except the clostripain.

High-Performance Liquid Chromatography Tandem Mass Spectrometry

The analytical system consisted of an Agilent 1200 liquid chromatograph coupled to an Agilent $6410 \mathrm{~A}-2 \mathrm{~K}$ triple quadrapole mass spectrometer (Palo Alto, CA). Instrumental parameters are listed in Table I. The mass spectrometer was operated in the multiple reaction monitoring (MRM) mode (Table II). The precursor ion for both GnRH and Peptide- 1 had a $\mathrm{z}$ value of 2 . Therefore, the base peak for each was found at half the mass of the molecule. Following collision in the mass spectrometer, the product ions were found to have $z$ values of 1 , This led to a situation in which the product ions had larger $\mathrm{m} / \mathrm{z}$ than the precursor ions for the quantification transition for each analyte. The proposed fragment ions can be seen in Figures 2 and 3. The $\mathrm{m} / \mathrm{z}$ of the precursor ions are given in the lower left corner of each figure. The lines indicate the site of fragmentation for each product ion as well as the corresponding $\mathrm{m} / \mathrm{z}$ value for each. The calibration standards ( 10 $-2,000 \mathrm{ng} / \mathrm{mL}$ ) were injected in triplicate and subjected to a weighted quadratic regression. Quantification was accomplished by comparing analyte responses to the external standard calibration curve.

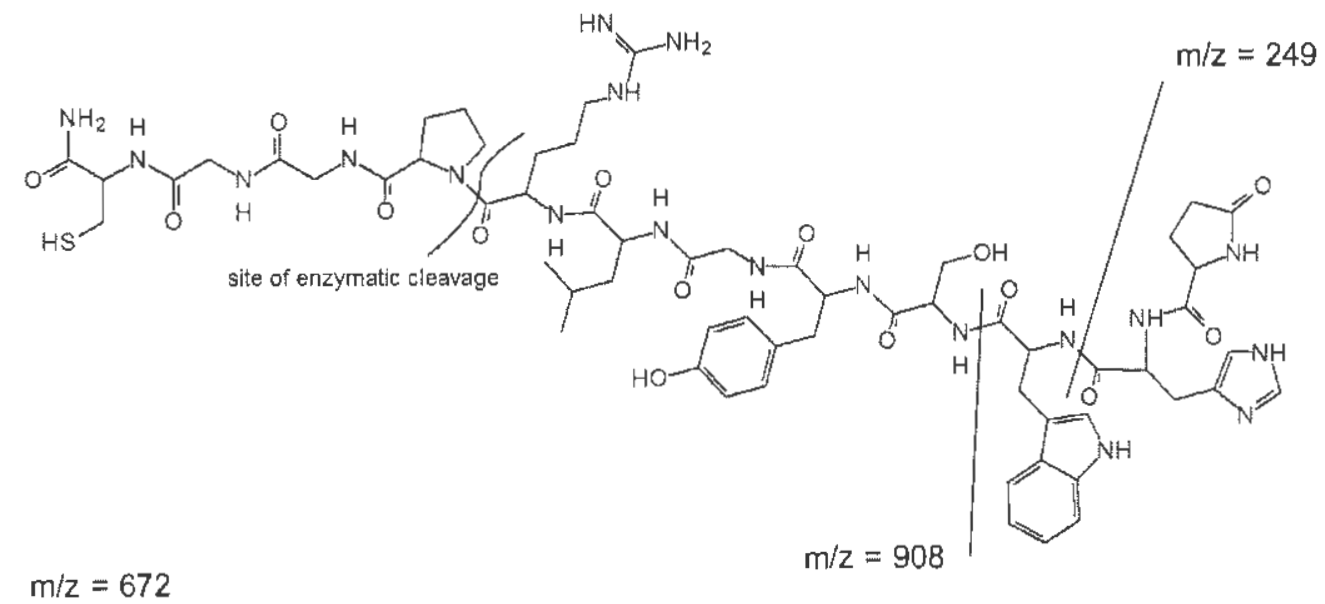

Figure 2. Mass fragmentation of $\mathrm{GnRH}$. 


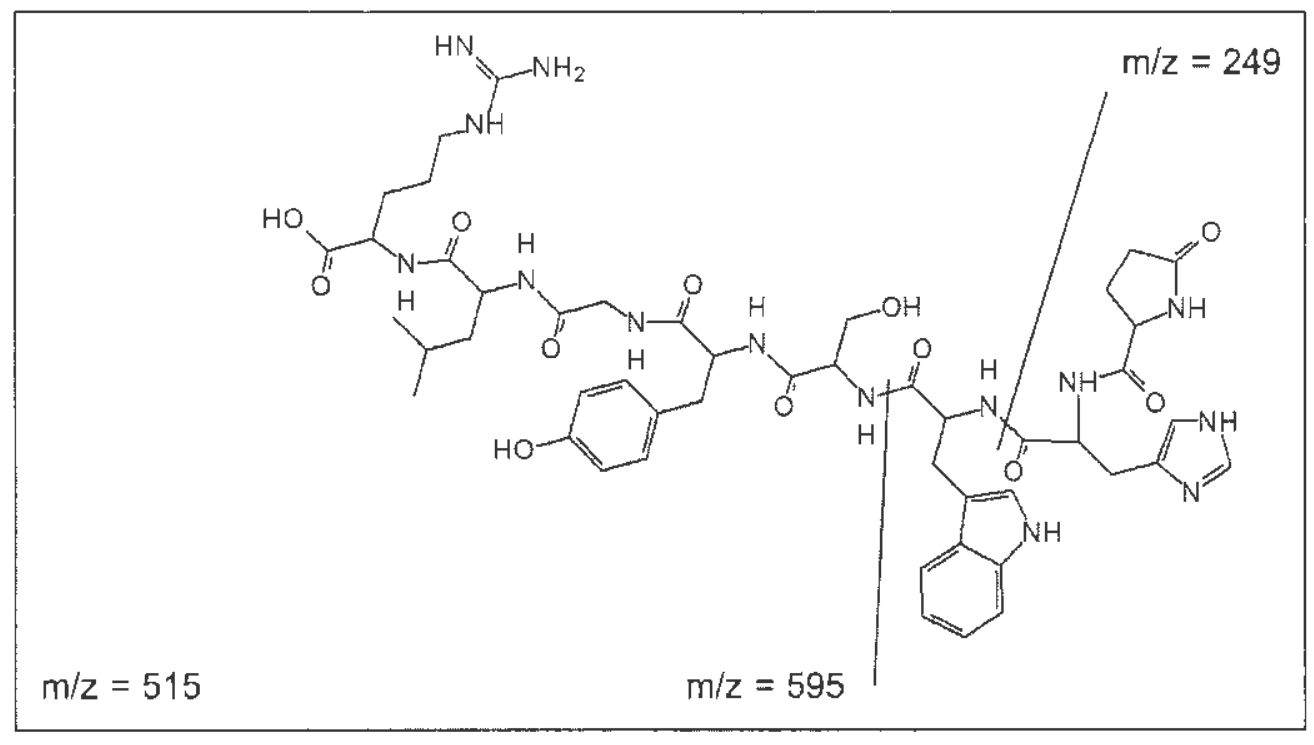

Figure 3. Mass fragmentation of Peptide-1.

\section{Quality Control Samples and Fortification of Controls}

A sham vaccine was prepared in the same manner as the GonaCon vaccine. This sham contained all of the components except GnRH and was prepared using the same protocols as the vaccine samples. The sham was fortified with a solution of $\mathrm{GnRH}$ in deionized water to produce fortification levels $50 \%$ above and below the target level for the vaccine $(300 \mu \mathrm{g} / \mathrm{mL})$. The quality control samples were extracted and analyzed using the same procedure described above.

\section{Results and Discussion}

\section{Enzymatic Cleavage}

The GonaCon ${ }^{\mathrm{TM}}$ vaccine is manufactured by conjugating the synthetic GnRH peptide to a mollusk hemocyanin protein via a sulfo-SMCC linker. Direct measurement of the fully conjugated protein was not possible due to the mass of the BP (approx.. $8 \mathrm{mDa}$ ). Attempts were made to analyze the final vaccine through the use of near infrared transflectance. This approach proved to be unfeasible possibly due to the high background created by the BP. The GnRH could easily be measured in solutions via HPLC, but not when linked to BP. The use of this linker produced a very stable and rugged link between the two 
components of the vaccine. However, this linkage is irreversible. Various solvents, acids, bases, and buffer treatments were investigated in an attempt to break this linkage. All efforts were unsuccessful. Clostripain is a proteinase isolated from Clostridium histolyticum which is highly specific for the carboxyl peptide bond of arginine and cleaves the GnRH at the cysteine residue in the conjugate (Figure 2) (19). This produces a smaller fragment of GnRH which has been called Peptide-1. Peptide-1 results from one GnRH molecule in a directly proportional relationship. Treatment of the sham vaccine with clostripain did not produce any measurable Peptide-1. By use of this enzyme, direct measurement of $\mathrm{GnRH}$ content in GonaCon vaccine was accomplished.

Table I. Instrument parameters

\begin{tabular}{|c|c|c|c|}
\hline Parameter & \multicolumn{3}{|c|}{ Conditions } \\
\hline Mobile Phase: & \multicolumn{3}{|c|}{$\begin{array}{l}\mathrm{A}=0.1 \% \text { formic acid in deionized water } \\
\mathrm{B}=0.1 \% \text { formic acid in acetonitrile }\end{array}$} \\
\hline \multirow[t]{5}{*}{ Gradient: } & Time & $\% \mathrm{~A}$ & $\% \mathrm{~B}$ \\
\hline & 0.0 & 90 & 10 \\
\hline & 1.0 & 90 & 10 \\
\hline & 5.0 & 60 & 40 \\
\hline & 5.5 & 10 & 90 \\
\hline Flow Rate: & \multicolumn{3}{|c|}{$0.5 \mathrm{~mL} / \mathrm{minute}$} \\
\hline Injection Volume: & \multicolumn{3}{|l|}{$20 \mu \mathrm{L}$} \\
\hline Column: & \multicolumn{3}{|c|}{$\begin{array}{l}\text { Agilent Rapid Resolution HT Zorbax SB-C3, } 100 \mathrm{~mm} \mathrm{x} \\
3.0 \mathrm{~mm} \text { i.d., } 1.8 \mu \mathrm{m}\end{array}$} \\
\hline Column Temperature: & \multicolumn{3}{|c|}{$80^{\circ} \mathrm{C}$} \\
\hline Detector Gas: & \multicolumn{3}{|c|}{ Nitrogen; $350^{\circ} \mathrm{C} ; 12.0 \mathrm{~L} /$ minute } \\
\hline Nebulizer Pressure: & \multicolumn{3}{|l|}{40 psi } \\
\hline Capillary Voltage: & \multicolumn{3}{|l|}{$4000 v$} \\
\hline MS1 Resolution: & \multicolumn{3}{|l|}{ Wide } \\
\hline MS2 Resolution: & \multicolumn{3}{|l|}{ Unit } \\
\hline Run Time: & \multicolumn{3}{|l|}{10 minutes } \\
\hline Post Time: & \multicolumn{3}{|l|}{3 minutes } \\
\hline
\end{tabular}


Table II. Multiple reaction monitoring transitions

\begin{tabular}{lcccc}
\hline Compound & Transition & Dwell (ms) & $\begin{array}{c}\text { Fragmentor } \\
(v)\end{array}$ & $\begin{array}{c}\text { Collision } \\
\text { Energy }(v)\end{array}$ \\
\hline GnRH & $672.0 \rightarrow 908.3$ & 75 & 132 & 24 \\
& $672.0 \rightarrow 249.1$ & 75 & 132 & 32 \\
Peptide-1 & $515.4 \rightarrow 595.3$ & 75 & 122 & 22 \\
& $515.4 \rightarrow 249.0$ & 75 & 122 & 20 \\
\hline
\end{tabular}

Additional problems were encountered while selecting the final extraction solution. The conjugated protein proved to be difficult to cleave with clostripain. Various buffers were used in an attempt to maximize the recovery of Peptide-1 from the GonaCon conjugate. It was hypothesized that the protein could be present in a folded conformation which might hinder the ability of the clostripain to cleave it. The use of 2,2,2-trifluoroethanol provided a minor denaturing effect which permitted the clostripain to cleave the GnRH. The enzyme system was optimized by investigation of the concentration of 2,2,2-trifluoroethanol which would permit the clostripain to still function while denaturing the conjugated GonaCon. A solution of $5 \%$ was found to be optimal. The time needed for the clostripain to cleave all of the GnRH present was also optimized. A reaction time of two hours was found to be sufficient for greater than $99 \%$ cleavage.

Table III. Analytical recoveries of free and total GnRH in sham vaccine quality control samples $(n=7)$

\begin{tabular}{ccccc}
\hline $\begin{array}{c}\text { Fortification Level } \\
(\mu g / g)\end{array}$ & Range $\%)$ & Mean $(\%)$ & Std. Dev. $\%)$ & CV (\%) \\
\hline Free GnRH & & & & \\
150 & $91.3-103$ & 99.3 & 4.1 & 4.1 \\
450 & $94.5-101$ & 98.2 & 2.3 & 2.3 \\
Total GnRH & & & & \\
150 & $106-127$ & 116 & 11 & 9.5 \\
450 & $110-124$ & 117 & 6.2 & 5.3 \\
\hline
\end{tabular}

\section{Quality Control Results}

Mean recoveries of free and total $\mathrm{GnRH}$ in sham vaccine $(n=7)$ quality control samples were excellent (Table III). 


\section{Method Limit of Detection}

The method limit of detection (MLOD) was estimated from the mean chromatographic response at the retention time of the parent $(\mathrm{GnRH})$ or product (Peptide-1) peptide plus three times the response standard deviation from seven replicate control samples. The mean and standard deviation for $\mathrm{GnRH}$ was measured and found to be $3.881 \pm 0.335 \mathrm{ng} / \mathrm{mL}$. The mean and standard deviation for Peptide- 1 was measured and found to be $1.577 \pm 0.458 \mathrm{ng} / \mathrm{mL}$. Using these values, the MLOD for GnRH was estimated to be $2.1 \mu \mathrm{g} / \mathrm{g}$ and the MLOD for Peptide- 1 was $1.6 \mu \mathrm{g} / \mathrm{g}$.

\section{GnRH Determination in GonaCon Vaccine}

Six replicate samples of a formulated GonaCon vaccine with a target content of $300 \mu \mathrm{g} / \mathrm{g}$ were analyzed by the procedures outlined above. The range of observed values was 151 to $199 \mu \mathrm{g} / \mathrm{g}$. The mean and standard deviation were 178 $\mu \mathrm{g} / \mathrm{g}$ and $18 \mu \mathrm{g} / \mathrm{g}$ respectively.

\section{Conclusion}

A highly selective and sensitive method for the determination of GnRH in GonaCon vaccines has been detailed. The method is repeatable and accurate. Use of this method will permit further investigation of the manufacturing and storage stability of this important wildlife management tool.

\section{Acknowledgments}

Thanks are due to the National Wildlife Research Center's (NWRC) Registration Unit for providing significant support and funding for the completion of this research. Thanks are also given to Darcy Orahood of the NWRC for preparation of the sham vaccine as well as numerous experimental vaccine formulations needed to develop this method. Mention of commercial products is for identification only and does not constitute endorsement by the U.S. Department of Agriculture.

\section{References}

1. Curtis, P. D.; Sullivan, K. L. Wildlife Damage Management Fact Sheet Series - White-Tailed Deer; Cornell Cooperative Extension: Ithaca, NY, 2001.

2. Woolf, A.; Roseberry, J. L. Wildl. Soc. Bull. 1998, 26, 515-521.

3. Cornell University Cooperative Extension - General Deer Population Facts; http://wildlifecontrol.info/deer/pages/deerpopulationfacts.aspx, accessed 11/ $20 / 11$.

4. Malo, J. E.; Suarez, F.; Diez, A. J. Appl. Ecol. 2004, 41, 701-710.

5. Russell, F. L.; Zippin, D. B.; Fowler, N. L. Am. Midl. Nat. 2001, 146, 1-26.

6. Rooney, T. P.; Waller, D. M. For. Ecol. Manage. 2003, 181, 165-76. 
7. Cote, S. D.; Rooney, T. P.; Tremblay, J.; Dussault, C.; Waller, D. M. Anmu. Rev. Ecol. Evol. Syst. 2004, 35, 113-47.

8. Lane, R. S.; Piesman, J,; Burgdorfer, W. Annu. Rev. Entomol. 1991, 36, 587-609.

9. Warren, R. J. Wildl. Soc. Bull. 1997, 25, 213-600.

10. Stout, R. J.; Knuth, B. A.; Curtis, P. D. Wildl. Soc. Bull. 1997, 25, 348-359.

11. Koehler, A. E.; Marsh, R. E.; Salmon, T. E. Proc. Vertebr. Pest. Conf. 1990, $14,168-173$.

12. VerCauteren, K. C.; Hygnstrom, S. E.; Pipas, M. J.; Fioranelli, P. B.; Werner, S. J.; Blackwell, B. F. Wildl. Soc. Bull. 2003, 31, 247-252.

13. VerCauteren, K. C; Vandeelen, T. R; Lavelle, M. J.; Hall, W. H. J. Wildl. Manage. 2010, 74, 1378-1381.

14. Warren, R. J. Anim. Prod. Sci. 2011, 51, 259-266.

15. Fagerstone, K. A.; Miller, L. A.; Killian, G.; Yoder, C. A. Integr: Zool. 2010, $1,15-30$.

16. Miller, L. A.; Johns, B. E.; Killian, G. J. Am. J. Reprod. Immunol. 2000, 44, 266-274.

17. Miller, L. A.; Giofriddo, J. P.; Fagerstone, K. A.; Rhyan, J. C.; Killian, G. J. Am. J. Reprod. Immunol. 2008, 60, 214-223.

18. Giofriddo, J. P.; Eisemann, J. D.; Sullivan, K. J.; Healey, R. S.; Miller, L. A.; Fagerstone, K. A. Wildl. Res. 2009, 36, 177-184.

19. Gilles, A. M.; 1mhoff, J. M.; Keil, B. J. Biol. Chem. 1979, 254, 1462-1468. 